\title{
KEABSAHAN PERJANJIAN PINJAM NAMA (NOMINEE) OLEH WARGA NEGARA ASING DALAM PENGUASAAN HAK MILIK ATAS TANAH DI INDONESIA*
}

\author{
Oleh \\ I Dewa Agung Dharma Jastrawan** \\ Dr. I Nyoman Suyatna, SH., $\mathrm{MH}^{* * *}$ \\ Bagian Hukum Bisnis \\ Fakultas Hukum Universitas Udayana
}

\begin{abstract}
ABSTRAK
Indonesia sebagai Negara kepulauan yang kekayaan alamnya telah diakui oleh dunia Internasional sangat menarik minat banyak wisatawan (warga negara asing). Warga negara asing yang masuk ke Indonesia, selain bertujuan wisata juga berupaya menanamkan modal untuk usaha dengan berbagai cara, salah satunya dengan cara menguasai tanah. Cara yang dilakukan oleh pihak-pihak tertentu yang tidak berhak memiliki hak milik atas tanah, adalah dengan mengunakan perjanjian nominee atau perjanjian pinjam nama. Tujuan dari penelitian ini yakni untuk mengetahui terkait Keabsahan dan akibat hukum dari perjanjian pinjam nama (nominee) oleh warga negara asing dalam penguasaan hak milik atas tanah di
\end{abstract}

* Penulisan karya ilmiah yang berjudul Keabsahan Perjanjian Pinjam Nama (Nominee) Oleh Warga Negara Asing Dalam Penguasaan Hak Milik Atas Tanah Di Indonesia ini bukan merupakan ringkasan skripsi (di luar skripsi).

** Penulis pertama dalam penulisan karya ilmiah ini selaku mahasiswa Fakultas Hukum Universitas Udayana.

${ }^{* * *}$ Penulis kedua dalam penulisan karya ilmiah ini selaku Pembimbing Akademik penulis pertama di Fakultas Hukum Universitas Udayana. 
Indonesia berdasarkan Kitab Undang-Undang Hukum Perdata dan Undang- Undang No. 5 Tahun 1960 tentang Peraturan Dasar Pokok- Pokok Agraria (UUPA). Penelitian yang digunakan dalam jurnal ini menggunakan metode penelitian hukum normatif. Perjanjian nominee yang digunakan oleh warga negara asing harus sesuai dengan syarat sahnya perjanjian dalam Pasal 1320 KUHPerdata. Perjanjian nominee tidak memenuhi unsur suatu sebab yang halal karena menyangkut pemindahan hak atas tanah dari warga negara Indonesia kepada warga negara asing secara tidak langsung, sehingga menyebabkan perjanjian nominee menjadi tidak sah. Dalam perjanjian nominee syarat objektif suatu sebab yang halal tidak dipenuhi maka mengakibatkan perjanjian tersebut menjadi batal demi hukum. Artinya dari semula suatu perjanjian dan/atau suatu perikatan dianggap tidak pernah dilahirkan/ tidak pernah ada.

\title{
Kata kunci: Keabsahan, Perjanjian Nominee, dan Hak Milik.
}

\begin{abstract}
Indonesia as an archipelago whose natural wealth has been recognized by the international community is very attractive to many tourists (foreign nationals). Foreign nationals who enter Indonesia, in addition to tourist destinations, also try to invest capital in businesses in various ways, one of them is by controlling the land. The way that certain parties do not have the right to ownership rights over land is by using a nominee agreement or a loan name agreement. The purpose of this study is to find out about the validity and legal consequences of nominee agreements by foreign citizens in the control of land ownership rights in Indonesia based on the Civil Code and Law No. 5 of 1960 concerning Basic Agrarian Principles Regulation (UUPA). The research method that used in this study is the normative research. Nominee agreements used by foreign nationals must be in accordance with the legal terms of the agreement in Article 1320 of the Civil Code. Nominee agreements do not fulfill the element of a
\end{abstract}


lawful reason because they involve the transfer of land rights from Indonesian citizens to foreign citizens indirectly, thus causing the nominee agreement to be invalid. In the nominee agreement a objective requirement is that halal is not fulfilled, resulting in the agreement being null and void by law. This means that from the beginning an agreement and / or an agreement was deemed never born / never existed.

\section{Keywords: Validity, Nominee Agreement, and Property Rights.}

\section{PENDAHULUAN}

\subsection{Latar Belakang}

Indonesia sebagai Negara kepulauan yang kekayaan alamnya telah diakui oleh dunia Internasional sangat menarik minat banyak wisatawan (warga negara asing). Orang asing yang datang ke Indonesia mempunyai tujuan yang beranekaragam dan berkunjung dalam jangka waktu yang lama ataupun berkunjung dalam jangka waktu yang singkat. Berbagai macam tujuan orang asing itu pada saat melakukan kegiatannya di Indonesia, mendorong keinginan orang asing untuk mempunyai tempat tinggal di Indonesia. Orang asing yang memilih untuk bertempat tinggal di Indonesia dapat menimbulkan dampak positif bagi perkembangan perekonomian di Indonesia salah satunya dengan melakukan investasi di Indonesia. ${ }^{1}$ Asumsi ini tak lain karena investasi asing telah menjadi bagian dari pembangunan ekomoni Indonesia yang dengan sendirinya terkait pula dengan ekonomi global ${ }^{2}$. Warga negara asing yang masuk ke Indonesia, selain bertujuan wisata juga berupaya menanamkan modal untuk usaha dengan berbagai cara,

1 Utami Jayanti, Made, 2018, "Pengaturan Perjanjian Pengikatan Jual Beli Atas Rumah Tempat Tinggal Oleh Warga Negara Asing Dengan Berlakunya Peraturan Menteri Agraria Dan Tata Ruang Nomor 29 Tahun 2016” Arta Comitas, Jurnal Hukum, Jurnal Kenotariatan, Vol 3. Hal.353

https://ojs.unud.ac.id/index.php/ActaComitas/article/view/44173

2 Yuni Osinbajo.1994.Hak Azas dan Ekonomi Pembangunan dalam Negara

Berkembang, Jakarta : PT. Gramedia Pustaka, Hal. 137. 
salah satunya dengan cara menguasai tanah. Perolehan tanah tersebut dilakukan dengan cara melakukan perjanjian jual beli tanah antara warga negara asing dengan warga negara Indonesia. Walaupun pemerintah telah memberikan kesempatan penguasaan tanah kepada warga negara asing berupa hak pakai dan hak sewa, namun dengan berbagai pertimbangan warga negara asing yang ingin berinvestasi di Indonesia khususnya di Bali tetap berkeinginan untuk memiliki tanah dengan status hak milik.

Dasar pertimbangan mengapa warga negara asing cenderung menginginkan hak milik adalah karena hak milik merupakan hak yang turun-temurun, terkuat dan terpenuh yang dapat dimiliki oleh seseorang atas tanah. Mengenai hak milik atas tanah oleh warga negara asing jelas dilarang oleh negara,berdasarkan Pasal 21 ayat (1) UUPA. Warga negara asing tidak dapat mempunyai hak milik atas tanah di Indonesia. Hak milik hanya bisa dimiliki oleh warga negara Indonesia dan badan hukum tertentu Indonesia.

Walaupun telah dilarang penguasaan Hak milik atas tanah di Indonesia oleh warga negara asing, namun pada kenyataannya banyak ditemukan kepemilikan hak atas tanah oleh warga negara asing yang dilakukan melalui cara sembunyi-sembunyi. Cara yang dilakukan oleh pihak-pihak tertentu yang tidak berhak memiliki hak milik atas tanah, adalah dengan mengunakan perjanjian nominee atau perjanjian pinjam nama, yang dimana biasanya perjanjian tersebut dilakukan oleh seorang warga negara Indonesia, namun hanya sebagai formalitas saja dan mewakili kepentingan pihak asing tertentu agar tidak menyalahi dan melanggar aturan perundang-undangan yang berlaku. ${ }^{3}$

${ }^{3}$ Maria S.W. Sumardjono, 2001, Kebijakan Pertanahan Antara Regulasi dan Implementasi, Kompas, Jakarta, h.7. 


\subsection{Rumusan Masalah}

1. Bagaimana Keabsahan Perjanjian Pinjam Nama (Nominee) Oleh Warga Negara Asing Dalam Penguasaan Hak Milik Atas Tanah Di Indonesia?

2. Bagaimana Akibat Hukum dari Perjanjian Pinjam Nama (Nominee) Oleh Warga Negara Asing Dalam Penguasaan Hak Milik Atas Tanah Di Indonesia?

\subsection{Tujuan Penulisan}

Tujuan dari penulisan tulisan ini yakni untuk mengetahui terkait Keabsahan dan akibat hukum dari Perjanjian Pinjam Nama (Nominee) Oleh Warga Negara Asing Dalam Penguasaan Hak Milik Atas Tanah Di Indonesia.

\section{ISI MAKALAH}

\subsection{METODE PENELITIAN}

Metode yang digunakan didalam penulisan makalah ini adalah metode penelitian hukum normatif dengan pendekatan perundang-undangan (The Statute Approach) artinya pendekatan yang dilakukan dengan menelah semua undang-undang dan regulasi yang bersangkut-paut sesuai hukum yang ditangani. 4 Bahan hukum diperoleh melalui bahan hukum yang telah diteliti dan selanjutnya akan dikumpulkan yang berkaitan dengan permasalahan penelitian ini untuk dilakukan pembahasan. ${ }^{5}$

4 Peter Mahmud Marzuki, 2010, Penelitian Hukum, Cetakan Keenam, Kencana Prenada Media Group, Jakarta, hal. 93.

5 Bambang Sunggono, 2010, Metodologi Penelitian Hukum, Rajawali Pers, Jakarta, h.86 


\subsection{HASIL DAN PEMBAHASAN}

\subsubsection{Keabsahan Perjanjian Pinjam Nama (Nominee) Oleh Warga Negara Asing Dalam Penguasaan Hak Milik Atas Tanah Di Indonesia}

Hak Milik sebagai hak terkuat dan terpenuh dilarang untuk dimiliki oleh WNA. Namun dalam praktik yang terjadi di daerah-daerah, masih banyak dijumpai WNA yang melakukan perbuatan hukum untuk dapat menguasai hak milik atas tanah tanpa memperhatikan ketentuan Undang- Undang Pokok Agraria (UU No. 5 Tahun 1960) selanjutnya disingkat UUPA. Perbuatan hukum ini biasanya dijumpai dalam bentuk perjanjian yang kemudian dikenal dengan perjanjian nominee.

Nominee adalah suatu perbuatan dimana warga negara Indonesia sebagai orang yang berhak memiliki hak atas tanah dengan hak milik meminjamkan namanya kepada pihak yang tidak berhak atas hak milik atas tanah atau warga negara asing agar warga negara asing tersebut dapat memiliki tanah secara hak milik. Warga negara Indonesia dalam melaksanakan perjanjian pinjam nama tersebut sebagai wakil bagi pihak asing dalam kepemilikan tanah. Perjanjian nominee tersebut dibuat agar seolah-oleh legal dan sesuai dengan aturan hukum yang berlaku, maka dibuatlah satu paket perjanjian antara warga negara asing sebagai penerima kuasa dan warga negara Indonesia sebagai pemberi kuasa yang memberikan kewenangan kepada warga negara asing untuk menguasai hak atas tanah dan melakukan segala perbuatan hukum terhadap tanah tersebut. 6 Pada umumnya warga negara asing melakukan pembelian tanah yang berstatus hak milik dengan

${ }^{6}$ Maria Sumardjono, 2007, Alternatif Kebijakan Pengaturan Hak atas Tanah Beserta Bangunan Bagi Warga Negara Asing dan Badan Hukum Asing, Kompas, Jakarta, hal. 2. 
meminjam nama seseorang warga negara Indonesia, warga negara Indonesia disini hanya sebagai orang yang namanya dipinjam dan dicantumkan di dalam sertifikat tanah atas Hak Milik akan tetapi penguasaan dan pemanfaatannya dimiliki oleh warga negara asing. Perjanjian Nominee tersebut digunakan sebagai suatu cara agar warga negara asing dapat memiliki tanah dengan hak milik di Indonesia dengan cara mendaftarkan tanah tersebut atas nama warga negara Indonesia yang ditunjuknya sebagai Nominee. Perjanjian Nominee merupakan jenis perjanjian nominat, yaitu perjanjian yang tidak dikenal dalam Kitab Undang-Undang Hukum Perdata (KUHPerdata) namun timbul, tumbuh dan berkembang di masyarakat.

Perjanjian Nominee adalah perjanjian tertulis antara dua belah pihak di mana satu pihak sepakat untuk melakukan suatu tindakan hukum yang seakan-akan pihak tersebut adalah sebagai pemegang saham, ataupun direktur sebuah perusahaan dan lain-lainnya, adapun tindakan hukum tersebut dilakukannya guna keperluan atau kepentingan dari pihak lainnya. Dengan membuat perjanjian nominee dengan warga negara Indonesia, yang memungkinkan berinvestasi sebagai pemegang saham maupun menguasai tanah hak milik, warga negara asing akan diyakinkan oleh warga negara Indonesia bahwa cara tersebut aman karena banyak dilaksanakan sebelumnya di masyarakat, hal ini benar adanya, namun cara tersebut ternyata tidak sah.

"Dalam praktek, minat pihak asing untuk memiliki tanah (tanpa atau beserta bangunan) yang berstatus Hak Milik atau Hak Guna Bangunan ditempuh melalui cara-cara yang sejatinya merupakan penyelundupan hukum."7 Penyelundupan hukum tersebut merupakan penyelundupan hukum yang melanggar

7 Maria S.W. Sumardjono, 1994, WNA dan Pemilikan Hak Milik Terselubung, Kompas, Jakarta, hal. 58. 
Undang-Undang. Karena Perjanjian nominee secara yuridis formal tidak menyalahi aturan, namun terdapat aturan yang jelas di dalam Pasal 26 ayat (2) UUPA yang menyatakan bahwa : "Setiap jual beli, penukaran, penghibahan, pemberian dengan wasiat dan perbuatan-perbuatan lain yang dimaksudkan untuk langsung atau tidak langsung memindahkan hak milik kepada orang asing, kepada seorang warga negara yang di samping kewarganegaraan Indonesia nya mempunyai kewarganegaraan asing atau kepada suatu badan hukum, kecuali yang ditetapkan Pasal 21 ayat (2), adalah batal karena hukum dan tanahnya jatuh kepada negara, dengan ketentuan, bahwa hak-hak pihak lain yang membebaninya tetap berlangsung serta semua pembayaran yang telah diterima oleh pemilik tidak dapat dituntut kembali."

Berdasarkan KUHPerdata, perjanjian nominee harus tunduk pada ketentuan-ketentuan hukum perjanjian dalam Buku III KUHPerdata. Berdasarkan KUHPerdata, perjanjian nominee yang digunakan oleh warga negara asing harus sesuai dengan syarat sahnya perjanjian dalam Pasal 1320 KUHPerdata. Pasal tersebut menentukan adanya 4 (empat) syarat sahnya perjanjian, yaitu:

1) Sepakat mereka yang mengikatkan dirinya;

2) Cakap untuk membuat suatu pejanjian;

3) Mengenai suatu hal tertentu; dan

4) Sesuatu sebab yang halal. ${ }^{8}$

Terkait dengan perjanjian nominee, maka keabsahannya dapat diuraikan sebagai berikut:

1) Kesepakatan mereka yang mengikatkan dirinya

8 Agus Bram Rendrajaya, Kadek, 2018, "Peraturan Hak Milik Atas Tanah Yang Di Alihkan Kepentingan Umum Perspektif Perlindungan Pemilik", Kerta Patrika Vol 40. Hal. 5

https://ojs.unud.ac.id/index.php/kerthapatrika/article/view/39991 
Para pihak sepakat mengadakan perjanjian mengenai hal-hal pokok dari perjanjian yang diadakan itu. Mereka menghendaki sesuatu yang sama secara timbal balik.

2) Kecakapan untuk membuat suatu perjanjian

Para pihak yang membuat perjanjian telah cakap menurut hukum. Pada asasnya, setiap orang yang sudah dewasa atau akil baliq dan sehat pikirannya, adalah cakap menurut hukum.

3) Suatu hal tertentu

Sebagai syarat ketiga disebutkan bahwa suatu perjanjian harus mengenai suatu hal tertentu, artinya apa yang diperjanjikan hak-hak dan kewajiban kedua belah pihak jika timbul suatu perselisihan. Barang yang dimaksudkan dalam perjanjian paling sedikit harus ditentukan jenisnya.

4) Suatu sebab yang halal

Syarat keempat untuk suatu perjanjian yang sah adalah adanya suatu sebab yang halal. Yang dimaksudkan dengan sebab atau causa dari suatu perjanjian adalah isi perjanjian itu sendiri, tidak boleh mengenai sesuatu yang terlarang. Terkait dengan hal ini maka, perjanjian nominee tidak memenuhi unsur suatu sebab yang halal karena menyangkut pemindahan hak atas tanah dari warga negara Indonesia kepada warga negara asing secara tidak langsung yang dilarang dalam Pasal 26 ayat (2) UUPA. Sehingga menyebabkan perjanjian nominee menjadi 
tidak sah/absah dan tidak memiliki kekuatan hukum mengikat bagi para pihaknya.

\subsubsection{Akibat Hukum dari Perjanjian Pinjam Nama (Nominee) Oleh Warga Negara Asing Dalam Penguasaan Hak Milik Atas Tanah Di Indonesia}

Secara umum warga negara asing hanya diperbolehkan menggunakan hak pakai atas tanah di wilayah Indonesia. UUPA Pasal 42 mengatur bahwa yang dapat mempunyai hak pakai adalah:

1) Warga Negara Indonesia;

2) Orang asing yang berkedudukan di Indonesia;

3) Badan hukum yang didirikan menurut hukum

4) Indonesia dan berkedudukan di Indonesia; danBadan hukum asing yang mempunyai perwakilan di Indonesia.

Sebagaimana telah diuraiakan di atas sahnya suatu perjanjian harus memenuhi ketentuaan Pasal 1320 KUH Perdata, memerlukan empat syarat, yaitu :

1) Kesepakatan mereka yang mengikatkan dirinya;

2) Kecakapan untuk membuat suatu perjanjian;

3) Suatu hal tertentu; dan

4) Suatu sebab yang halal.

Dari keempat syarat diatas, kesepakatan dan cakap membuat kontrak adalah syarat subyektif, apabila tidak dipenuhi syarat tersebut maka perjanjian yang dibuat dapat dibatalkan oleh salah satu pihak. Sedangkan suatu hal tertentu dan sebab yang halal merupakan syarat obyektif, apabila syarat tersebut tidak terpenuhi maka perjanjian yang dibuat adalah batal demi hukum.

Karena di dalam perjanjian nominee syarat objektif suatu sebab yang halal tidak dipenuhi maka mengakibatkan perjanjian 
tersebut menjadi batal demi hukum. Artinya dari semula suatu perjanjian dan/atau suatu perikatan dianggap tidak pernah dilahirkan/ tidak pernah ada. Tujuan para pihak yang mengadakan perjanjian tersebut untuk melahirkan suatu perikatan hukum adalah gagal. Sebagaimana dikatakan Maria S.W Sumardjono bahwa, "Substansi perjanjian tersebut melanggar syarat objektif dan oleh karena itu adalah batal demi hukum.

Pasal 1335 KUHPerdata menyatakan bahwa suatu perjanjian yang dibuat dengan kausa palsu atau terlarang tidak mempunyai kekuatan. Dalam hal ini, perjanjian itu dianggap sudah batal dari semula karena tidak semua perjanjian yang dibuat mempunyai kekuatan mengikat sebagai undang-undang. Hanya perjanjian yang sah yang mengikat kedua belah pihak. Dengan demikian perjanjian pura-pura tidak mempunyai kekuatan mengikat karena dibuat tidak sah. ${ }^{9}$

Selain berdasarkan ketentuan di Kitab Undang-Undang Hukum Perdata, menurut Pasal 26 ayat (2) UUPA, perjanjian pinjam nama (nominee) juga dilarang dan pelanggaran terhadap pasal ini berakibat batal demi hukum terhadap perjanjian tersebut.

\section{PENUTUP}

\subsection{Kesimpulan}

1. Perjanjian nominee harus tunduk pada ketentuan-ketentuan hukum perjanjian dalam Buku III KUHPerdata. Perjanjian nominee yang digunakan oleh warga negara asing harus sesuai dengan syarat sahnya perjanjian dalam Pasal 1320 KUHPerdata. Pasal tersebut menentukan adanya 4 (empat) syarat sahnya perjanjian, yaitu: Sepakat mereka yang mengikatkan dirinya; Cakap

\footnotetext{
${ }^{9}$ Maria S.W Sumardjono, Op.cit, hal.85
} 
untuk membuat suatu pejanjian; Mengenai suatu hal tertentu; dan Sesuatu sebab yang halal. Terkait dengan hal ini maka, perjanjian nominee tidak memenuhi unsur suatu sebab yang halal karena menyangkut pemindahan hak atas tanah dari warga negara Indonesia kepada warga negara asing secara tidak langsung yang dilarang dalam Pasal 26 ayat (2) UUPA. Sehingga menyebabkan perjanjian nominee menjadi tidak sah/absah dan tidak memiliki kekuatan hukum mengikat bagi para pihaknya.

2. Di dalam perjanjian nominee syarat objektif suatu sebab yang halal tidak dipenuhi maka mengakibatkan perjanjian tersebut menjadi batal demi hukum. Artinya dari semula suatu perjanjian dan/atau suatu perikatan dianggap tidak pernah dilahirkan/ tidak pernah ada. Pasal 1335 KUHPerdata menyatakan bahwa suatu perjanjian yang dibuat dengan kausa palsu atau terlarang tidak mempunyai kekuatan. Dalam hal ini, perjanjian itu dianggap sudah batal dari semula karena tidak semua perjanjian yang dibuat mempunyai kekuatan mengikat sebagai undang-undang.

\subsection{Saran}

1. Bagi para pihak yang melakukan perjanjian nominee, sebaiknya mengurungkan niatnya tersebut. Dikarenakan perbuatan tersebut termasuk penyelundupan hukum, yang dapat menimbulkan permasalahan hukum kedepannya.

2. Bagi Notaris/PPAT selaku pelaksana Undang-undang, agar memegang teguh dan melaksanakan sumpah/janji 
jabatan yang diucapkan sebelum memulai tugas dan jabatannya sebagai bentuk tanggung jawab kepada Negara Republik Indonesia sehingga lebih mengedepankan unsur kehati-hatian dan menerapkan hukum sesuai dengan peraturan perundang-undangan yang berlaku. Notaris seharusnya memberikan informasi melalui penyuluhan hukum kepada para penghadap baik kepada WNI maupun WNA yang akan menuangkan kehendak ke dalam suatu akta sehingga tercipta perlindungan hukum serta kepastian hukum melalui produk hukum akta notaris. 


\section{DAFTAR PUSTAKA}

\section{Buku :}

Marzuki, Peter Mahmud, 2010, Penelitian Hukum, Cetakan Keenam, Kencana Prenada Media Group, Jakarta.

Udiana, Made, 2011, Rekonstruksi Peraturan Penyelesaian Sengketa Penanaman Modal Asing, Udayana University Press, Denpasar-Bali

Subekti, 1996, Pokok-Pokok Hukum Perdata, PT. Intermasa, Jakarta.

Sumardjono, Maria, 1994, WNA dan Pemilikan Hak Milik Terselubung, Kompas, Jakarta. , 2001, Kebijakan Pertanahan Antara Regulasi dan Implementasi, Kompas, Jakarta. , 2007, Alternatif Kebijakan Pengaturan Hak atas Tanah Beserta Bangunan Bagi Warga Negara Asing dan Badan Hukum Asing, Kompas, Jakarta.

Sunggono, Bambang, 2010, Metodologi Penelitian Hukum, Rajawali Pers, Jakarta.

\section{Jurnal :}

Utami Jayanti, Made, 2018, "Pengaturan Perjanjian Pengikatan Jual Beli Atas Rumah Tempat Tinggal Oleh Warga Negara Asing Dengan Berlakunya Peraturan Menteri Agraria Dan Tata Ruang Nomor 29 Tahun 2016” Arta Comitas, Jurnal Hukum, Jurnal Kenotariatan, Vol 3.

https://ojs.unud.ac.id/index.php/ActaComitas/article/view/4413 Agus Bram Rendrajaya, Kadek, 2018, "Peraturan Hak Milik Atas

Tanah Yang Di Alihkan Kepentingan Umum Perspektif Perlindungan Pemilik”, Kerta Patrika Vol 40.

https://ojs.unud.ac.id/index.php/kerthapatrika/article/view/399 
Perundang-undangan :

Kitab Undang - Undang Hukum Perdata

Undang- Undang No. 5 Tahun 1960 tentang Peraturan Dasar Pokok- Pokok Agraria (UUPA) 